\begin{tabular}{|c|c|c|}
\hline orts $i$ & \multicolumn{2}{|c|}{ Case Rep Gastroenterol 2014;8:89-94 } \\
\hline Gastroenterology & $\begin{array}{l}\text { DOI: } 10.1159 / 000356818 \\
\text { Publisned ontine: IVarch 19, } 2014\end{array}$ & $\begin{array}{l}\text { (c) } 2014 \text { S. Karger AG, Basel } \\
1662-0631 / 14 / 0081-0089 \$ 39.50 / 0 \\
\text { www.karger.com/crg }\end{array}$ \\
\hline & \multicolumn{2}{|c|}{$\begin{array}{l}\text { This is an Open Access article licensed under the terms of the Creative Common } \\
\text { Attribution-NonCommercial } 3.0 \text { Unported license (CC BY-NC) (www.karger.com/OA } \\
\text { license), applicable to the online version of the article only. Distribution permitted for non } \\
\text { commercial purposes only. }\end{array}$} \\
\hline
\end{tabular}

\title{
Gastroduodenal Intussusception Caused by a Gastric Collision Tumor Consisting of Adenocarcinoma and Neuroendocrine Carcinoma
}

\author{
Yoshihiko Kadowaki Takeshi Nishimura Satoshi Komoto \\ Takeshi Yuasa Ryuji Tamura Takahiro Okamoto Nobuhiro Ishido
}

Department of Surgery, Kobe Red Cross Hospital, Kobe, Japan

\section{Key Words}

Gastroduodenal intussusception · Gastric collision tumor · Neuroendocrine carcinoma

\begin{abstract}
Adenocarcinoma is the most common histological type of gastric tumor. Gastric tumor arising from collision of an adenocarcinoma with a neuroendocrine carcinoma is extremely rare. Moreover, this uncommon gastric collision tumor in our case had prolapsed into the duodenum. A 77-year-old woman was admitted to our hospital complaining of vomiting and severe weight loss. Abdominal X-ray showed gastric distension, and computed tomography revealed a duodenal giant mass spreading from the bulb to the horizontal part of the duodenum. Upper gastrointestinal endoscopy was not helpful in confirming the diagnosis of the tumor. We suspected duodenal malignant tumor and performed laparotomy. The operative findings indicated that the gastric antrum was deeply invaginated into the duodenum because of the gastric tumor. Partial resection of the stomach and duodenum was performed because the tumor was irreducible. Intraoperative diagnosis of the frozen section was welldifferentiated adenocarcinoma and undifferentiated carcinoma. Additional distal gastrectomy with lymphadenectomy was performed. We herein report the first case of gastroduodenal intussusception caused by a gastric collision tumor consisting of well-differentiated adenocarcinoma and poorly differentiated neuroendocrine carcinoma.
\end{abstract}


Kadowaki et al.: Gastroduodenal Intussusception Caused by a Gastric Collision Tumor Consisting of Adenocarcinoma and Neuroendocrine Carcinoma

\section{Introduction}

Intussusception of the adult intestinal tract is an unusual condition and varies considerably from that in children. The diagnosis can be delayed because of its long-standing, intermittent and nonspecific symptoms. Gastric collision tumors are often found, however most tumors are composed of carcinoid or lymphoma and adenocarcinoma. The coexistence of neuroendocrine tumors and adenocarcinoma is extremely rare. To the best of our knowledge, there is no report of gastroduodenal intussusception by a gastric collision tumor consisting of well-differentiated adenocarcinoma and poorly differentiated neuroendocrine carcinoma (PDNEC).

\section{Case Report}

A 77-year-old woman presented with vomiting for 1 month and loss of $25 \%$ of body weight during that time. She had previously visited a general practitioner for vomiting. Abdominal X-ray in that clinic had indicated gastric dilatation. She was referred to our hospital for further examination.

On physical examination, her abdomen was bloated without tenderness. She was $143 \mathrm{~cm}$ tall and weighed $30 \mathrm{~kg}$. Vital signs were: body temperature $36.8^{\circ} \mathrm{C}$, pulse 65 beats per minute, respiratory rate 18 per minute, and blood pressure 90/60 mm Hg. Laboratory data on admission were as follows: white blood cell count $5,800 / \mu \mathrm{l}$, red blood cell count $326 \times 10^{4} / \mu \mathrm{l}$, hemoglobin $10.2 \mathrm{~g} / \mathrm{dl}$, platelets $35.1 \times 10^{4} / \mu \mathrm{l}$, total protein $4.4 \mathrm{~g} / \mathrm{dl}$, albumin $2.1 \mathrm{~g} / \mathrm{dl}$, total bilirubin $0.38 \mathrm{mg} / \mathrm{dl}$, aspartate aminotransferase $13 \mathrm{IU} / \mathrm{l}$, alanine aminotransferase $6 \mathrm{IU} / \mathrm{l}$, alkaline phosphatase $68 \mathrm{IU} / \mathrm{l}, \gamma$-glutamyl transferase $12 \mathrm{IU} / \mathrm{l}$, cholinesterase $99 \mathrm{IU} / \mathrm{l}$, total cholesterol $103 \mathrm{mg} / \mathrm{dl}$, blood urea nitrogen $17.1 \mathrm{mg} / \mathrm{dl}$, creatinine $0.42 \mathrm{mg} / \mathrm{dl}$, C-reactive protein $1.20 \mathrm{mg} / \mathrm{dl}$, Na $134 \mathrm{mEq} / \mathrm{l}, \mathrm{K} 3.61 \mathrm{mEq} / \mathrm{l}, \mathrm{Cl} 97 \mathrm{mEq} / \mathrm{l}, \mathrm{CEA} 4.7 \mathrm{ng} / \mathrm{ml}$, and CA19-9 7.3 U/ml. Abdominal X-ray showed gastric dilatation. Computed tomography (CT) of the abdomen revealed a duodenal giant mass spreading from the bulb to the horizontal part of the duodenum (fig. 1). Upper gastrointestinal radiography with Gastrografin revealed smooth taper shape of the duodenum. No tumor was clearly detected (fig. 2a). A villous tumor was observed in the duodenal bulb endoscopically, but the pyloric ring was not confirmable (fig. 2b). There were no appearances suggestive of malignancy. The tissue obtained from biopsy did not include malignant cells. Insertion of the endoscope into the second part of the duodenum was easy.

We diagnosed the mass to be a huge duodenal tumor, and laparotomy was therefore performed. About one third of the stomach was invaginated through the pylorus into the duodenum (fig. 3). We in vain performed manipulative reduction by Hutchinson's maneuver. Gastrotomy followed by duodenotomy was performed and revealed a villous tumor measuring $12 \mathrm{~cm}$ in maximum diameter. The tumor was excised and pathological examination of the frozen section showed malignant cells composed of well-differentiated adenocarcinoma and undifferentiated carcinoma. The infrapyloric lymph node was positive for metastasis. Therefore, additional distal gastrectomy with lymphadenectomy was performed. The patient made an uneventful postoperative recovery. 
Kadowaki et al.: Gastroduodenal Intussusception Caused by a Gastric Collision Tumor Consisting of Adenocarcinoma and Neuroendocrine Carcinoma

\section{Discussion}

Adult intussusception occurs infrequently and its diagnosis can be delayed because of nonspecific symptoms. In adults, 90\% occur in the small or large intestine, and gastroduodenal intussusception is extremely uncommon [1]. The lead point of the gastroduodenal intussusception is usually a pedunculated benign gastric tumor [2]. Polyps constitute $40 \%$ and intramural smooth muscle tumors $40 \%$ [3]. In general, the diagnosis can be made easily by upper gastrointestinal series and CT. However, we misdiagnosed invaginated gastric tumor into the duodenum as a giant duodenal tumor. CT with oral contrast might have been useful on diagnosis. Ishikawa et al. [4] summarized the Japanese literature with a collection of 125 cases of gastroduodenal intussusception by gastric cancer. To the best of our knowledge, there is no report of gastroduodenal intussusception by a gastric collision tumor.

Collision tumors are thought to arise from morphologically different neighboring neoplasms that do not intermingle [5]. Most neoplasms that develop in the stomach are adenocarcinomas, whereas gastric neuroendocrine tumors represent less than $1 \%$ of all gastric neoplasms [6]. In addition, in the stomach, the coexistence of neuroendocrine tumors and adenocarcinoma is extremely rare, and most tumors are composed of carcinoid or lymphoma and adenocarcinoma $[7,8]$. In our case, frozen section of the surgical specimen showed only malignant cells composed of well-differentiated adenocarcinoma and undifferentiated carcinoma. However, the fixed specimens were found to be a gastric collision tumor consisting of well-differentiated adenocarcinoma and PDNEC through detailed pathological examination. Macroscopically the collision tumor composed of two morphologically different lesions can be seen (fig. 4). In immunohistochemical staining, the lesion of PDNEC was positive for neuronal cell adhesion molecule, but the lesion of papillary adenocarcinoma gave a negative result (fig. 5). We only found one previous report of gastric collision tumor consisting of neuroendocrine carcinoma (NEC) and adenocarcinoma [9]. Meanwhile, Nishikura et al. [10] demonstrated that $70.6 \%$ of gastric NEC cases included an adenocarcinoma component in the mucosa and/or submucosa. In our case, both PDNEC and adenocarcinoma were clearly distinguished not only by morphological but also by histological findings, suggesting that we can classify the present tumor as a collision tumor.

The biological behavior of gastric NEC is significantly more aggressive than that of ordinary adenocarcinoma [11]. Therefore, intensive chemotherapy is recommended for gastric NEC; however, the patient refused any recommended chemotherapy. In general, combination chemotherapy using cisplatin and etoposide (PE) and cyclophosphamide, doxorubicin and etoposide (CDE) have been employed for the treatment of NEC [12]. Recently, Okita et al. [13] showed the efficacy of a combination therapy with cisplatin and irinotecan for PDNEC. In our case, multiple metastatic hepatic and splenic tumors became clinically overt after 6 months of follow-up without any adjuvant chemotherapy.

We herein report the first case of gastroduodenal intussusception caused by a gastric collision tumor consisting of well-differentiated adenocarcinoma and PDNEC.

\section{Disclosure Statement}

The authors have no conflict of interest. 


\section{Case Reports in
Gastroenterology}

\begin{tabular}{l|l}
\hline Case Rep Gastroenterol 2014;8:89-94 \\
\hline DOI: 10.1159/000356818 & $\begin{array}{l}\text { @ 2014 S. Karger AG, Basel } \\
\text { www.karger.com/crg }\end{array}$ \\
\hline
\end{tabular}

Kadowaki et al.: Gastroduodenal Intussusception Caused by a Gastric Collision Tumor Consisting of Adenocarcinoma and Neuroendocrine Carcinoma

\section{References}

1 Stubenbord WT, Thorbjarnarson B: Intussusception in adults. Ann Surg 1970;172:306-310.

-2 Lin F, Setya V, Signor W: Gastroduodenal intussusception secondary to a gastric lipoma: a case report and review of the literature. Am Surg 1992;58:772-774.

-3 Sankaranunni B, Ooi DS, Sircar T, Smith RC, Barry J: Gastric lipoma causing gastroduodenal intussusception. Int J Clin Pract 2001;55:731-732.

4 Ishikawa T, Kyogoku T, Takamine Y, Hayashi M: A case of advanced gastric cancer prolapsing into the duodenum. J Jap Surg Assoc 2003;64:2153-2156.

$\$ 5$ Klaase JM, Hulscher JB, Offerhaus GJ, ten Kate FJ, Obertop H, van Lanschot JJ: Surgery for unusual histopathologic variants of esophageal neoplasms: a report of 23 cases with emphasis of histopathologic characteristics. Ann Surg Oncol 2003;10:261-267.

-6 Klöppel G, Anlauf M: Epidemiology, tumour biology and histopathological classification of neuroendocrine tumours of the gastrointestinal tract. Best Pract Res Clin Gastroenterol 2005;19:507-517.

7 Kim EY, Park KC, Kwon JG: A case of double primary cancer: early gastric adenocarcinoma associated with adenocarcinoma and carcinoid. Korean J Gastroenterol 2003;42:533-538.

8 Goteri G, Ranaldi R, Rezai B, Baccarini MG, Bearzi I: Synchronous mucosa-associated lymphoid tissue lymphoma and adenocarcinoma of the stomach. Am J Surg Pathol 1997;21:505-509.

-9 Jang KY, Moon WS, Lee H, Kim CY, Park HS: Gastric collision tumor of large cell neuroendocrine carcinoma and adenocarcinoma - a case report. Pathol Res Pract 2010;206:387-390.

10 Nishikura K, Watanabe H, Iwafuchi M, Fujiwara T, Kojima K, Ajioka Y: Carcinogenesis of gastric endocrine cell carcinoma: analysis of histopathology and p53 gene alteration. Gastric Cancer 2003;6:203-209.

11 Jiang SX, Mikami T, Umezawa A, Saegusa M, Kameya T, Okayasu I: Gastric large cell neuroendocrine carcinomas: a distinct clinicopathologic entity. Am J Surg Pathol 2006;30:945-953.

12 Moertel CG, Kvols LK, O'Connell MJ, Rubin J: Treatment of neuroendocrine carcinomas with combined etoposide and cisplatin. Evidence of major therapeutic activity in the anaplastic variants of these neoplasms. Cancer 1991;68:227-232.

13 Okita NT, Kato K, Takahari D, Hirashima Y, Nakajima TE, Matsubara J, Hamaguchi T, Yamada Y, Shimada Y, Taniguchi H, Shirao K: Neuroendocrine tumors of the stomach: chemotherapy with cisplatin plus irinotecan is effective for gastric poorly-differentiated neuroendocrine carcinoma. Gastric Cancer 2011;14:161-165.

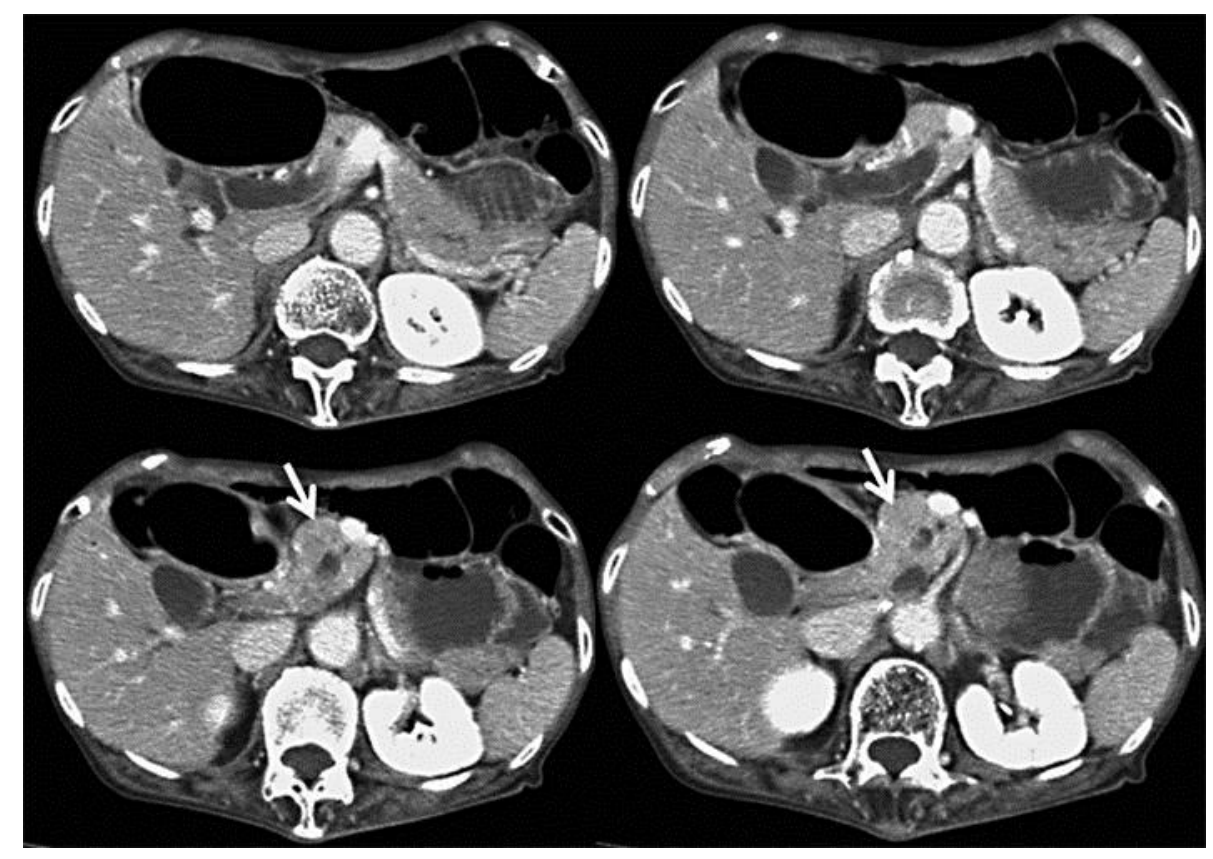

Fig. 1. CT scan of the abdomen showing a duodenal giant mass spreading from the bulb to the horizontal part of the duodenum (arrows). 


\begin{tabular}{l|l}
\hline Case Rep Gastroenterol 2014;8:89-94 \\
\hline DOI: 10.1159/000356818 & $\begin{array}{l}\text { ○ 2014 S. Karger AG, Basel } \\
\text { www.karger.com/crg }\end{array}$ \\
\hline
\end{tabular}

Kadowaki et al:: Gastroduodenal Intussusception Caused by a Gastric Collision Tumor Consisting of Adenocarcinoma and Neuroendocrine Carcinoma
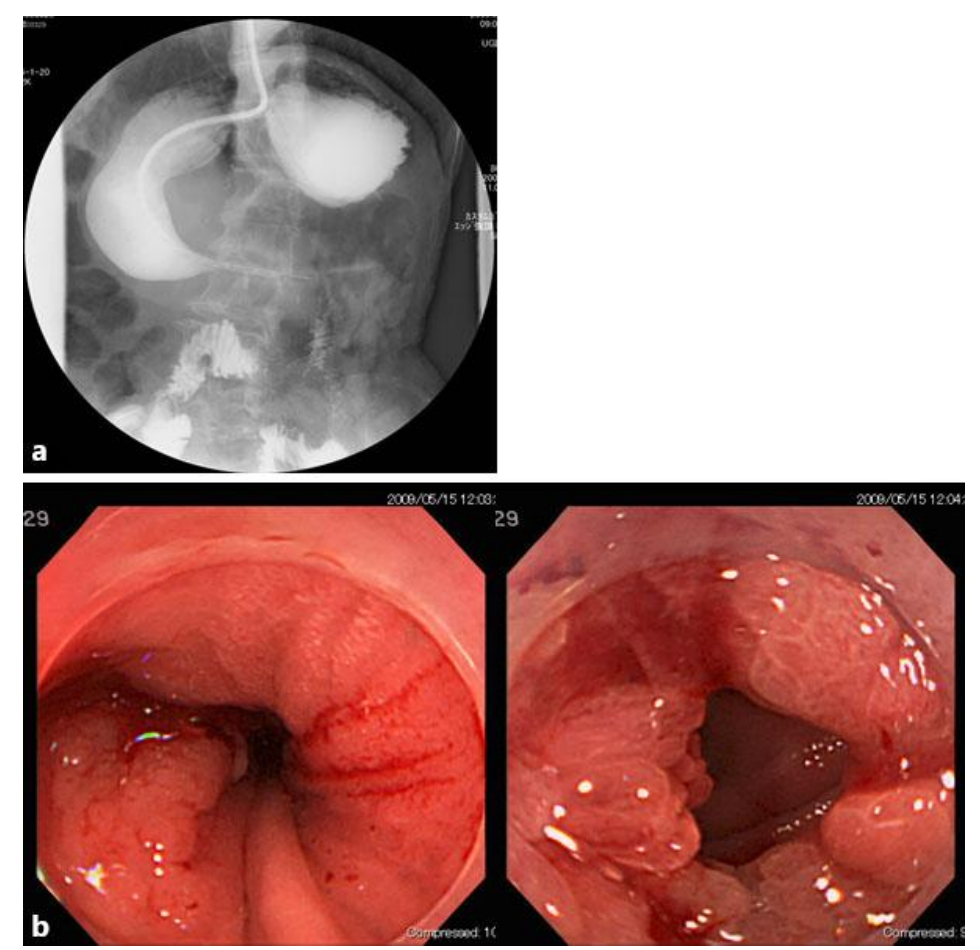

Fig. 2. a Upper gastrointestinal radiography with Gastrografin revealed smooth taper shape of the duodenum. b A villous tumor was observed in the duodenal bulb endoscopically, but the pyloric ring was not confirmable.

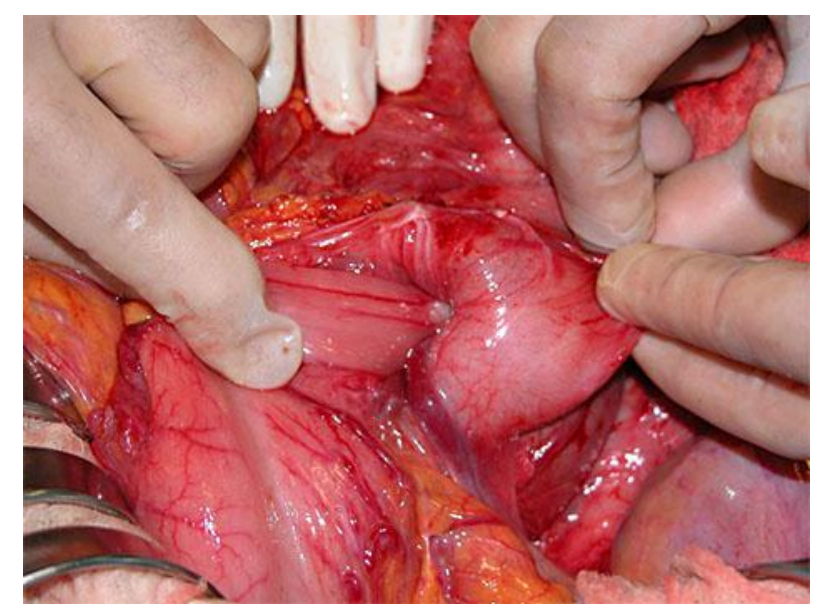

Fig. 3. Gastroduodenal intussusception as found at operation. 


\section{Case Reports in
Gastroenterology}

\begin{tabular}{l|l}
\hline Case Rep Gastroenterol 2014;8:89-94 \\
\hline DOI: 10.1159/000356818 & $\begin{array}{l}\text { @ 2014 S. Karger AG, Basel } \\
\text { www.karger.com/crg }\end{array}$ \\
\hline
\end{tabular}

Kadowaki et al.: Gastroduodenal Intussusception Caused by a Gastric Collision Tumor Consisting of Adenocarcinoma and Neuroendocrine Carcinoma
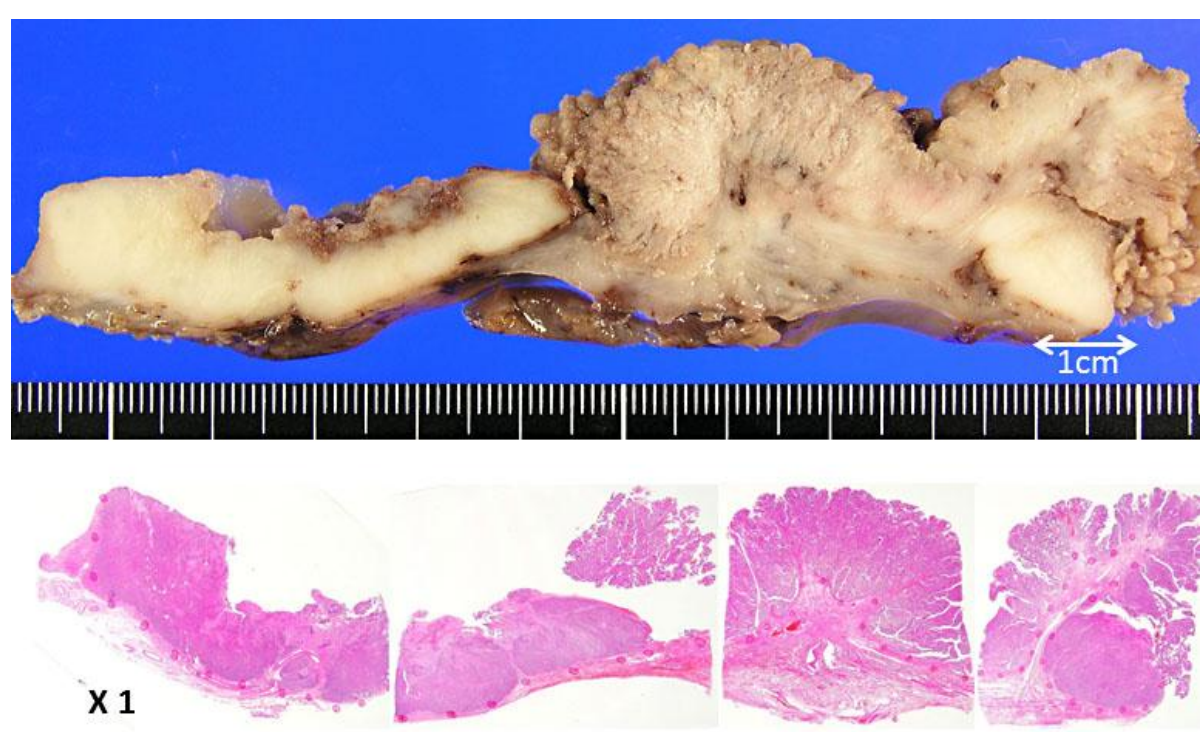

Fig. 4. Macroscopic findings showing collision of tuberous and villous formation.
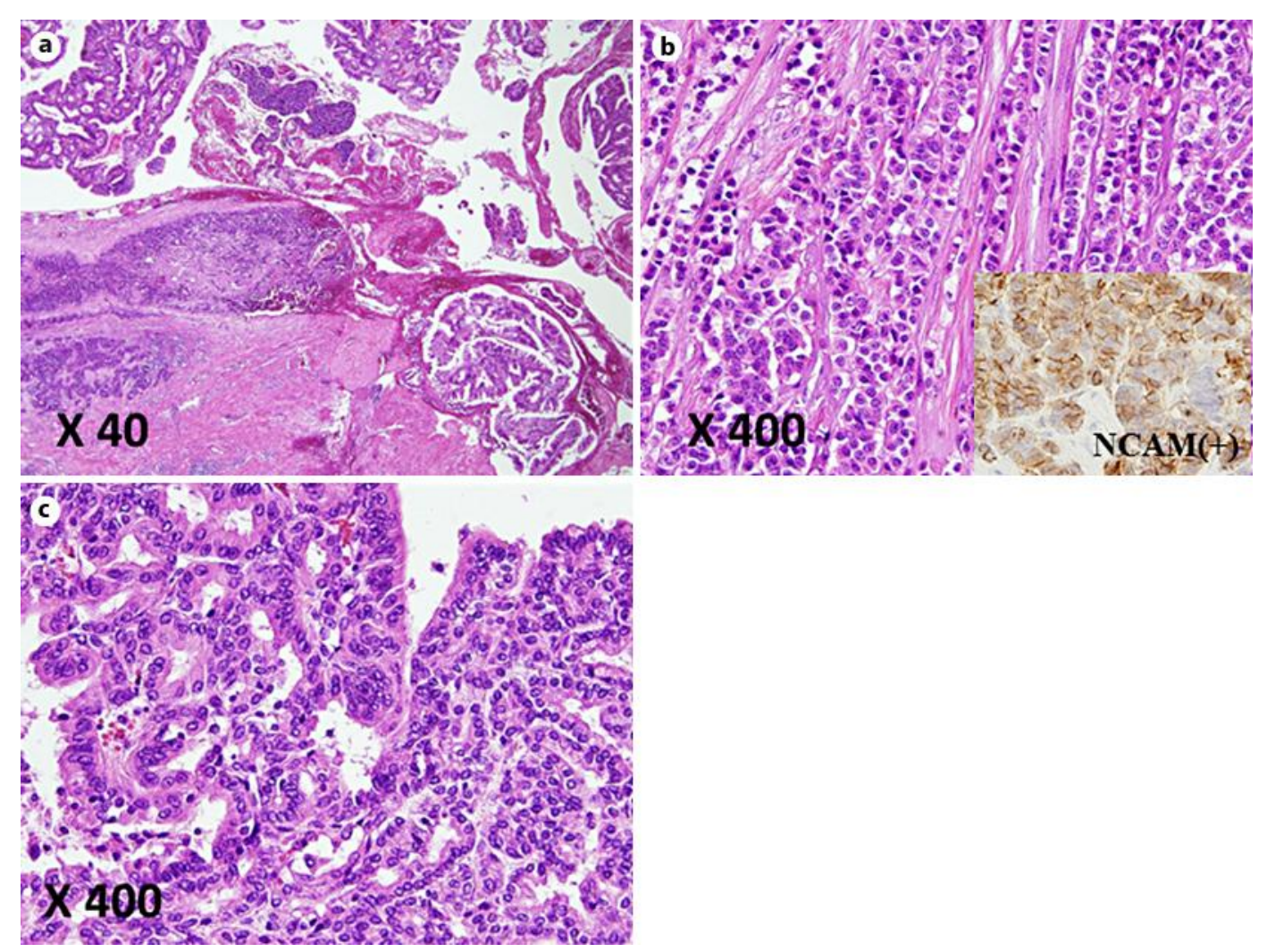

Fig. 5. Pathological evaluation of two lesions. a The colliding point of adenocarcinoma (pap, tub1) and PDNEC. $\mathbf{b}$ The poorly differentiated carcinoma showing neuronal cell adhesion molecule expression (inset). c The villous lesion showing well-differentiated adenocarcinoma. 